\title{
Debris removal efficiency depend on different ultrasonic irrigation protocols
}

\author{
Gun Heo1, Jin-Woo Kim¹, Kyung-Mo Cho1, Nyamsuren Enkhbileg ${ }^{1,2}$, Eun-Hye Lee ${ }^{1,3}$, Se-Hee Park ${ }^{1 *}$ \\ ${ }^{1}$ Department of Conservative Dentistry, College of Dentistry, Gangneung-Wonju National University, Gangneung, Republic of Korea

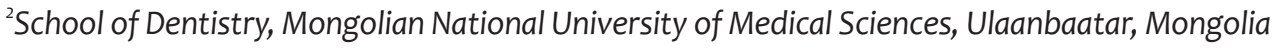 \\ ${ }^{3}$ Division of Conservative Dentistry, Department of Dentistry, College of Medicine, Hanyang University, Seoul, Republic of Korea
}

Purpose: The purpose of this study is comparing the efficiency of debris removal of passive ultrasonic irrigation depend on different protocols. Materials and Methods: Forty-eight mandibular premolars were randomly divided into 2 groups depend on vibration power (Weak and Strong, $n=24$ ). And then two groups were subdivided into 3 groups depend on the number of times that PUI used $(1,2$ and $3, n=8)$. After standardization, teeth were split into two halves. On the wall of one half of root canal, three depressions were cut at 1, 3 and $5 \mathrm{~mm}$ from the apex and in the same way two depressions were cut on the other half of root canal at 2, $4 \mathrm{~mm}$ from the apex. Each depression was filled with mixture of dentine and $\mathrm{NaOCl}$. After irrigation, images of the root canal wall were taken, and then the amount of remaining dentine debris was evaluated. Results: There was no significant difference between weak and strong power of vibration groups. Weak vibration groups did not show significant difference depend on the different number of times PUI used. But in the strong vibration groups, twice and three times used groups show better removal efficiency. Conclusion: The removal efficiency of dentine debris is not significantly different depend on the power of vibration. And multiple use of PUI could have better irrigating effects at the apical third area in the strong vibration group. (J Dent Rehabil Appl Sci 2020;36(2):104-11)

Key words: canal irrigation; mandibular premolar; passive ultrasonic irrigation; the number of times, vibration power

\begin{abstract}
서론
근관치료의 기본적인 원칙 중 하나는 감염되거나 괴사 된 치수조직과 미생물을 근관계에서 제거하는 것이며, 이 것은 가장 결정적이고 중요한 근관치료의 성공 요건으로 작용한다. ${ }^{1,2}$ 그러나 리본 형태, 타원형의 근관, 좁은 협부 (isthmus) 등과 같은 해부학적인 이유로 근관 내 많은 부 위가 기계적으로 세정이 불가능하며, 이로 인해 세균이 나 다른 미생물들이 잔존하게 된다. ${ }^{3,4}$ Peters 등 ${ }^{5}$ 의 연구 에 따르면 Ni-Ti 기구를 사용하여 근관을 성형 할 때, 성 형 방법에 상관 없이 근관 내에 기계적으로 성형 되지 않
\end{abstract}

*Correspondence to: Se-Hee Park

Professor, Department of Conservative Dentistry, College of Dentistry, Gangneung-Wonju National University, 7, Jukheon-gil, Gangneung-si, Gangwondo, 25457, Republic of Korea

Tel: +82-33-640-2760, Fax: +82-33-640-3103, E-mail: drendo@gwnu.ac.kr

Received: April 22, 2020/Last Revision: May 7, 2020/Accepted: May 28, 2020
은 부위가 최소 $35 \%$ 이상 존재하였다고 한다. 따라서 항 균작용을 갖는 근관세척액의 사용을 통한 근관 세정이 기계적인 근관 형성과 병행되어야 한다. ${ }^{6}$

일반적으로 근관세척액은 시린지와 needle tip을 이용 하여 수동적으로 적용하게 된다. 이 방법은 needle tip을 통해 정확한 접근이 가능하고, 액체를 다시 채울 수 있으 며, 커다란 잔사 조각들을 씻어내어 직접적으로 세균과 의 접촉이 가능한 장점이 있다. 그러나 세척액의 교환이 needle tip에서 1 - $1.5 \mathrm{~mm}$ 범위로 제한되며, 이 부근에서 만 역동적인 용액의 흐름이 발생한다. ${ }^{78}$ 또한 needle의 직 경과 근관 내에서의 위치에 따라 세정의 효율성이 결정

CopyrightC 2020 The Korean Academy of Stomatognathic Function and Occlusion. (c) It is identical to Creative Commons Non-Commercial License. 
되기 때문에 좁고 만곡된 근관에서는 그 효과가 제한된 다. ${ }^{9,10}$

Passive ultrasonic irrigation (PUI)는 1980년 Weller 등 에 의해 소개되었으며, "passive" 라는 용어는 초음파로 작동하는 파일이나 와이어가 "non-cutting" 특성을 갖는 것을 의미한다. ${ }^{11}$ PUI는 초음파를 이용하여 근관 내 세척 액에 에너지를 전달하는 방식이며, 근관의 손상과 변형 을 막을 수 있고, 음향유동과 공동현상을 이용하여 기존 의 방식보다 도말층과 상아질 잔사, 박테리아를 효율적 으로 제거할 수 있다. ${ }^{2}$ 또한 측방근관과 같이 도달하기 어려운 부분의 세정도 가능하게 할 수 있다. ${ }^{13-15}$

PUI는 근관을 최종 확대까지 시행한 이후 적용하는 것 이 추천되며, 근관 내에서 끼이지 않도록 작고 매끈한 파 일이나 와이어의 적용이 추천된다. 근관을 미리 확대해 놓음으로써 근관 내에서 기구가 자유롭게 움직일 수 있 으며, 이로 인해 세척액이 근관의 근단부까지 적용 될 수 있기 때문에 세정 효과가 증가하게 된다. ${ }^{16,17}$

그러나 PUI 적용 프로토콜은 제조사별로 다양하며, 이 에 대한 연구 결과도 다양한 차이를 보여서 직접적으로 비교하기 어렵다. 따라서 본 연구에서는 근관 성형 및 근 관 확대를 시행한 근관계에 인위적으로 형성한 불규칙한 부위에서 PUI 적용 강도, PUI 적용 횟수에 따른 상아질 잔사 제거 효율성에 대해 비교하여 임상에서 보다 효율 적인 근관 세정 방법을 알아보고자 하였다.

\section{연구 재료 및 방법}

단일 근관인 발거된 하악 소구치 중 만곡이 심한 근관 을 갖거나 파절 및 미세균열과 같은 치아의 결함을 포함 한 치아는 배제하였고, 치근흡수로 인해 치근단공이 넓 어진 치아 또한 제외하여 총 48 개의 치아를 준비하였다. 본 연구는 임상시험심사위원회의(IRB2017-19)를 거친 후 연구를 진행하였다.

치아의 치관 부위를 삭제하여 치근을 $16 \mathrm{~mm}$ 길이 로 표준화하였으며, 근관 와동을 형성한 이후 근관장을 $15 \mathrm{~mm}$ 로 설정하여 실제 근관 길이로부터 $1 \mathrm{~mm}$ 떨어 진 부위까지 근관을 성형하였다. \#15 K파일(Dentsply Mailleffer, Ballaigues, Switzerland)로 치근단공에서 첨 단 부위가 보일 때까지 삽입하여 patency를 확보하였고, glide path를 형성하였다. 이후 근관을 ProTaper Universal system (Dentsply Maillefer, Ballaigues, Switzerland) 을 이용하여 S1부터 F4까지 근관장만큼 근관 형성 및 확
대를 시행하였다. Lee 등 $^{12}$ 의 연구방법을 참고하여, 매 근관 형성 과정마다 $12 \mathrm{~mL}$ Blue Endo Lock syringe와 27-gauge needle tip (Kaili, Zhaoyuan, China)을 사용해 서 $2.5 \% \mathrm{NaOCl} 2 \mathrm{~mL}$ 로 근관을 세척하였다.

각 치아를 $0.15 \mathrm{~mm}$ 두께를 갖는 다이아몬드 디스크 (911HF; Komet, Lemgo, Germany)로 치아 장축에 평행 한 방향으로 구를 형성한 후 chisel을 이용하여 종단방향 으로 절반으로 분리시켰다.

치아의 상아질벽에 근관벽의 불규칙한 부위를 표현하 기 위해서, 직경 $0.5 \mathrm{~mm}$ 의 No. $1 / 4$ round bur (H1.005; Komet)를 사용하여 한쪽 상아질벽에는 치근첨에서 1,3 , $5 \mathrm{~mm}$ 의 거리에 직경 $0.5 \mathrm{~mm}$, 깊이 $0.5 \mathrm{~mm}$ 의 함요를 형 성하였고, 반대쪽 상아질벽에는 치근첨에서 $2,4 \mathrm{~mm}$ 의 거리에 같은 형태의 함요를 형성하였다(Fig. 1).

실험군과 별개로 종단으로 분리한 치아 근관벽의 상아 질을 직경 $1.4 \mathrm{~mm}$ 의 No. 4 round bur (H1.014; Komet) 를 이용하여 상아질 잔사를 만들었다. 이후 $2.5 \% \mathrm{NaOCl}$ 과 5 분간 혼합시켜 sand-like mixture가 되도록 하고, 실 험군의 각 함요와 근관 내부에 혼합물을 채웠다. $15 \times$ $15 \mathrm{~mm}$ 로 제작된 플라스틱 주형에 퍼티 인상재(Exafine

A

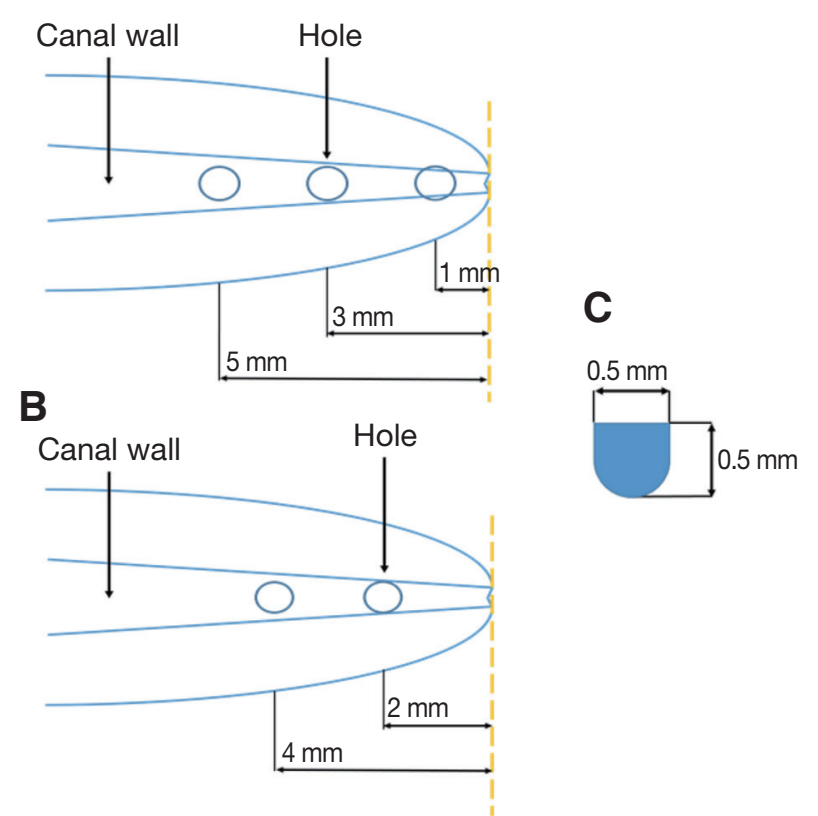

Fig. 1. Schematic representation of specimen preparation. (A) On one half of the root canal, three depressions were cut at 1, 3 and $5 \mathrm{~mm}$ from the apex, (B) On the other half, two depressions were cut at 2, $4 \mathrm{~mm}$ from the apex, (C) Cross section of the depression. 
Putty; GC, Tokyo, Japan)를 채워 넣고 절반으로 분리된 두 절편을 재조합하여 묻은 후에 경화시켰다.

이후 총 48 개의 치아를 PUI 적용 방법에 따라 6 개의 그룹으로 분류하였다. PUI 적용 강도에 따라 'Weak', 'Strong' 2개의 그룹으로 나누었고, PUI 적용 횟수에 따 라 ' 1 회', '2회', '3회’의 3 개 그룹으로 나누어 총 6 개의 그 룹으로 실험을 진행하였다.

Mini Endo II Ultrasound (SybronEndo, Glendora, USA)와 Endosonic PS tip (SelectD, Seoul, Korea)을 이 용하여 세정을 시행하였다(Fig. 2, 3). Mini Endo II의 경 우 제조사에 따르면 $25-32 \mathrm{kHz}$ 의 초음파 진동수를 가 지며, 본체의 적용 강도 조절 버튼을 통해 편리하게 조절 이 가능하다고 한다. Endosnic PS tip은 제조사에 따르 면 Poly Ether Ether Ketone (PEEK)을 이용하여 유연 성이 매우 뛰어나며 근관 내 상아질 벽에 손상을 가하지 않고 안전한 세정이 가능하다고 한다. 본 실험에서는 길 이 $20 \mathrm{~mm}, \# 20 / .03$ size tip을 사용하였다.

Weak 그룹에서는 $2.5 \% \mathrm{NaOCl}$ 과 Mini Endo II의 적 용 강도는 “1”로 설정하였다. 먼저 $2 \mathrm{~mL}$ 부피의 $\mathrm{NaOCl}$ 로 세정하고 초음파 기구를 30 초간 작동한 뒤 최종 세정 시에 $12 \mathrm{~mL}$ 의 $\mathrm{NaOCl}$ 을 적용하였다. 초음파 기구의 tip 은 근관장보다 $1 \mathrm{~mm}$ 짧은 지점까지 위치시킨 후에 작동 시켰다. Strong 그룹 역시 같은 방법으로 실험을 진행하 되 적용 강도를 " 10 "으로 설정하였다.

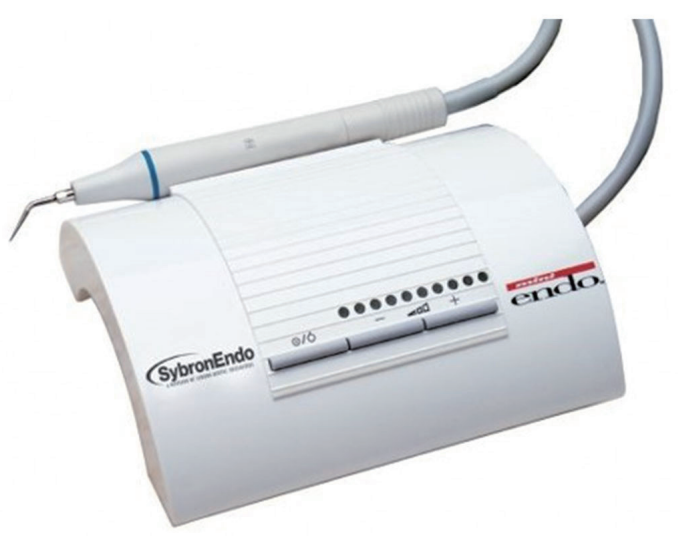

Fig. 2. Mini Endo II Ultrasound (SybronEndo, Glendora, USA).
적용 횟수를 증가시킨 그룹에서는 1 회의 그룹과 같이 초음파 세정을 시행한 이후 초음파 기구의 사용 간격마 다 $2 \mathrm{~mL}$ 부피의 $\mathrm{NaOCl}$ 을 사용하여 세정하였다. 총 세척 액의 부피는 따라서 1 회 그룹에서는 $14 \mathrm{~mL}, 2$ 회 그룹에 서는 $16 \mathrm{~mL}, 3$ 회 그룹에서는 $18 \mathrm{~mL}$ 의 $\mathrm{NaOCl}$ 을 사용하 였다.

이러한 세정 과정 이후 상아질 잔사 제거의 효율성을 비교하기 위해 퍼티 인상재를 제거하고 치아를 다시 분 리하였다. 입체현미경(SZ4045; Olympus, Tokyo, Japan) 으로 두 절편의 근관벽을 20 배 확대하여 촬영한 후 $\mathrm{PC}$ 로 이미지를 전송하였다. 이미지 상에서 함요에 잔존하는 상아질 잔사의 양을 0 - 3으로 구분하는 점수 체계를 이 용하여 점수를 부여하였는데, 이는 0 에서 3 까지 단계별 로 점수가 존재하고 score 0: 와동 내에 잔사 없음; score 1: 와동 내에 절반 이하의 잔사 존재; score 2: 와동 내에 절반 이상의 잔사 존재; score 3 : 와동 전체가 잔사로 채 워짐을 의미한다(Fig. 4). ${ }^{11}$

PUI 적용 강도 차이에 따른 통계적 유의성을 검증하 기 위하여 Mann-Whitney U-test를 이용하였고, PUI 적 용 횟수 차이에 따른 통계적 유의성을 검증하기 위하여 Kruskal-Wallis test를 이용하였다. 통계처리에는 SPSS 통계 분석 프로그램(IBM SPSS Statistics 25.0, SPSS INC., Chicago, USA)을 이용하였다.

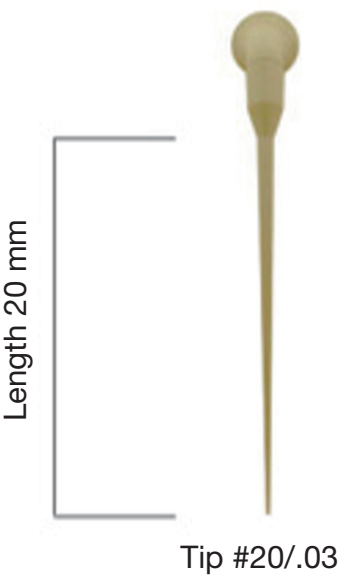

Fig. 3. Endosonic PS tip (SelectD, Seoul, Korea). 

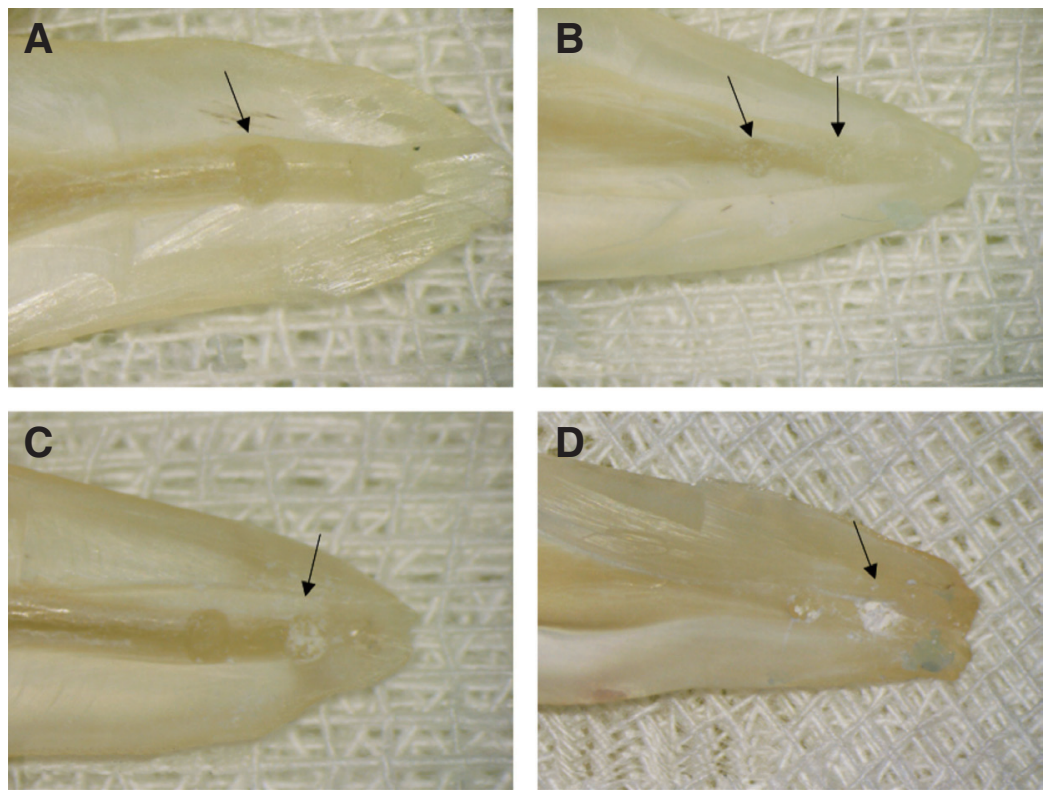

Fig. 4. Digital images of samples after irrigation. Each sample shows scoring system depend on the amount of remained dentine debris. (A) score $0,(B)$ score $1,(C)$ score 2, (D) score $3(\times 20)$.

\section{결과}

각 실험군의 함요에서 근관 세정 이후 잔존 상아질 잔 사의 양에 대해 Table 1에 나타내었다. 그리고 KruskalWallis test와 Mann-Whitney U-test를 이용하여 PUI 적 용 횟수에 따른 유의성 분석 결과를 Table 2 - 3 에 나타내
었다. PUI 적용 강도 차이에 따른 유의성은 관찰되지 않 았으며, PUI 적용 횟수에 따른 유의성은 Weak 그룹에서 는 보이지 않았으나, Strong 그룹에서는 치근첨으로부터 1 - $4 \mathrm{~mm}$ 거리의 함요에서 관찰되었다. 이에 대해 MannWhitney U-test를 이용한 사후분석 결과 1회 적용 그룹 과 2회 적용 그룹을 비교 시 치근첨으로부터 $2,3 \mathrm{~mm}$ 거

Table 1. Dentine debris score (means \pm standard deviation) - Holes $1 \mathrm{~mm}$ to $5 \mathrm{~mm}$ from apex

\begin{tabular}{lllllll}
\hline & $\mathrm{W} 1(\mathrm{n}=8)$ & $\mathrm{W} 2(\mathrm{n}=8)$ & $\mathrm{W} 3(\mathrm{n}=8)$ & $\mathrm{S} 1(\mathrm{n}=8)$ & $\mathrm{S} 2(\mathrm{n}=8)$ & $\mathrm{S} 3(\mathrm{n}=8)$ \\
\hline $1 \mathrm{~mm}$ & $1.50 \pm 0.926$ & $1.63 \pm 1.506$ & $1.63 \pm 1.408$ & $2.38 \pm 0.744$ & $1.50 \pm 0.926$ & $1.38 \pm 0.518$ \\
$2 \mathrm{~mm}$ & $1.13 \pm 0.641$ & $1.00 \pm 0.926$ & $0.75 \pm 0.707$ & $1.88 \pm 0.835$ & $0.88 \pm 0.991$ & $0.63 \pm 0.744$ \\
$3 \mathrm{~mm}$ & $1.25 \pm 0.886$ & $0.50 \pm 0.535$ & $0.50 \pm 0.535$ & $1.13 \pm 0.641$ & $0.38 \pm 0.744$ & $0.38 \pm 0.518$ \\
$4 \mathrm{~mm}$ & $0.63 \pm 0.744$ & $0.38 \pm 0.518$ & $0.13 \pm 0.354$ & $0.63 \pm 0.518$ & $0.25 \pm 0.413$ & 0 \\
$5 \mathrm{~mm}$ & $0.5 . \pm 0.535$ & $0.25 \pm 0.463$ & $0.38 \pm 0.518$ & $0.38 \pm 0.518$ & $0.13 \pm 0.354$ & $0.25 \pm 0.463$ \\
\hline
\end{tabular}

W1: Weak, Once, W2: Weak, Twice, W3: Weak, Three times, S1: Strong, Once, S2: Strong, Twice, S3: Strong, Three times.

Table 2. Kruskal-Wallis test result on debris scores of weak and strong group depend on different number of passive ultrasonic irrigation used

\begin{tabular}{lcc}
\hline & Strong $(\mathrm{n}=24)$ & Weak $(\mathrm{n}=24)$ \\
\hline $1 \mathrm{~mm}$ & $0.037^{*}$ & 0.999 \\
$2 \mathrm{~mm}$ & $0.023^{*}$ & 0.594 \\
$3 \mathrm{~mm}$ & $0.040^{*}$ & 0.088 \\
$4 \mathrm{~mm}$ & $0.025^{*}$ & 0.252 \\
$5 \mathrm{~mm}$ & 0.528 & 0.600 \\
\hline
\end{tabular}

${ }^{*} P$-values with statistically significant difference $(P<0.05)$.
Table 3. Mann-Whitney U-test result on debris scores of strong group depend on number of passive ultrasonic irrigation used

\begin{tabular}{cccc}
\hline & S1 - S2 & S1 - S3 & S2 - S3 \\
\hline $1 \mathrm{~mm}$ & 0.060 & $0.014^{*}$ & 0.729 \\
$2 \mathrm{~mm}$ & $0.035^{*}$ & $0.012^{*}$ & 0.646 \\
$3 \mathrm{~mm}$ & $0.036^{*}$ & $0.028^{*}$ & 0.747 \\
$4 \mathrm{~mm}$ & 0.143 & $0.028^{*}$ & 0.143 \\
$5 \mathrm{~mm}$ & 0.264 & 0.602 & 0.535 \\
\hline
\end{tabular}

${ }^{*} P$-values with statistically significant difference $(P<0.05)$. 
리의 함요에서, 1 회 적용 그룹과 3 회 적용 그룹을 비교 시 치근첨으로부터 $5 \mathrm{~mm}$ 거리의 함요를 제외한 모든 부위 에서 적용 횟수의 증가에 따른 상아질 잔사의 유의미한 감소를 보였다. 2 회 적용 그룹과 3 회 적용 그룹 간에 유 의한 차이는 관찰되지 않았다.

\section{고찰}

근관 성형시 이용되는 수동기구와 회전식 기구는 근관 을 원형으로 형성하는 경향이 있어, ${ }^{18}$ 타원형의 근관에서 기구조작이 안된 부위가 남은 채 근관이 성형되는 경우 가 다수 있다. ${ }^{19}$ 또한 근관계의 해부학적 복잡성 역시 근 관 세정 및 근관치료의 실패를 야기할 수 있으므로, ${ }^{20}$ 본 실험에서는 근관에 불규칙한 부위를 형성하여 기구 조작 이 되지 않은 근관을 재현하여 PUI의 근관 세정 효과를 조사 하였다.

3 개의 clinical case와 45 개의 in vitro 연구를 포함하여 총 48 개의 연구를 포함한 systematic review를 살펴보면, 이 연구들의 PUI power setting이 $10 \%$ 에서 $100 \%$ 까지 다양하였으며, PUI 적용 횟수 역시 1회부터 3회 이상까 지 매우 다양한 프로토콜에 따른 것을 확인할 수 있었다. 해당 논문에서는 이러한 다양한 프로토콜이 상이한 실험 결과에 대한 원인일 수 있음을 지적하였으며, PUI의 표 준화된 프로토콜의 사용이 필요함에 대해 언급하였다. ${ }^{21}$ 따라서 PUI의 적용 강도 및 적용 횟수를 비교하여 프로 토콜을 제시하기 위하여 다양한 조건에서 본 실험을 진 행하게 되었다.

본 실험 결과에서 PUI 적용 강도에 따른 상아질 잔사 제거의 효율성 비교 시 모든 부위에서 유의한 차이를 보 이지 않았다. 그러나 치근첨으로부터 $1,2 \mathrm{~mm}$ 거리의 함 요에서 1회 적용 시 Strong 그룹이 Weak 그룹에 비해 더 높은 점수를 보이는 경향이 있다(Table 1). 이는 강도가 증가할 때 진폭의 증가 및 근관 내 세척액의 유속의 증가 를 유도하여 공동현상이 더욱 활성화 되며, 세정력이 증 가하라 수 있다는 이전 연구들과는 일치하지 않는 결과 였다. ${ }^{22,23}$

Verhaagen 등 $^{24}$ 에 의하면 강도의 증가가 유속의 증가 와 함께 근관 내 압력 및 전단 응력의 증가를 유도하게 될 수 있다고 하였으며, Macedo 등 ${ }^{25}$ 은 압력의 증가는 동 시에 "Rectified diffusion" 이라는 현상에 의해 "Stable bubble"의 형성을 촉진 시킬 수 있다고 하였다. Rectified diffusion이란 초음파 진동이 가해질 때 액체 속의 기포
가 팽창하고 수축하는 것을 반복하는 현상이다. 일반적 인 세정 과정에서는 bubble이 터지면서 근관 내의 상아질 잔사에 에너지를 전달하게 되지만, stable bubble의 형성 은 오히려 $\mathrm{NaOCl}$ 과 잔사 사이에서 직접적인 접촉을 방 해하는 효과를 보일 수 있다고 하였다. 이는 근단부 부위 에서 시린지를 이용한 세척시 나타나는 vapor lock과 비 슷한 효과 일 수 있다. ${ }^{25-27}$

따라서 적용 강도의 증가 시 공동현상의 활성화와, stable bubble 형성에 의한 근관 내 세정 효과의 약화가 서로 상충될 수 있으므로 적절한 강도의 설정이 PUI 적 용 시 필수적일 것으로 사료된다. 실제 몇몇 PUI 제조사 에서는 근관벽의 손상 가능성 및 세정 효과를 고려하여 $30-35 \%$ 의 강도로 사용할 것을 추천하고 있다. ${ }^{21}$

PUI 적용 횟수에 따른 상아질 잔사 제거의 효율성을 비교해보면 Strong 그룹에서는 치근첨으로부터 $5 \mathrm{~mm}$ 거리의 함요를 제외하고 모두 통계적으로 유의미한 차이 를 보였으나, Weak 그룹에서는 모두 통계적으로 유의미 한 차이를 보이지 않았다(Table 2). 이후 Strong 그룹 내 에서 Mann-Whitney U-test를 통한 사후분석 결과 1회 적용 그룹과 2회 적용 그룹은 치근첨으로부터 $2,3 \mathrm{~mm}$ 거리의 함요에서, 1 회 적용 그룹과 3 회 적용 그룹은 치근 첨으로부터 $5 \mathrm{~mm}$ 거리의 함요를 제외한 모든 부위에서 적용 횟수의 증가에 따른 상아질 잔사의 유의미한 감소 를 보였다. 2 회 적용 그룹과 3 회 적용 그룹 간에 유의한 차이는 관찰되지 않았다(Table 3). 이는 PUI 적용 횟수의 증가 시, 적용 간격마다 근관 세정액을 통한 세정이 추가 되어 총 양이 증가하였고 이로 인해 내부의 잔사 제거가 더 효과적으로 이루어지면서 PUI의 효과가 더욱 증대된 것으로 사료된다. 또한 Boutsioukis 등 ${ }^{26}$ 은 vapor lock이 시린지를 이용한 세척으로 제거될 수 있다고 언급하였는 데, stable bubble의 제거 역시 시린지를 이용한 세척의 적 용이 영향을 줄 수 있을 것으로 보인다. 따라서 PUI의 다 회 적용 및 flushing action과 함께 시린지를 통한 $\mathrm{NaOCl}$ 의 충분한 적용이 잔사 및 stable bubble의 제거에 더 효 과적일 것으로 사료된다.

현재 PUI 적용 시 일반적으로 사용하는 tip의 재질은 폴리머나 금속이 주를 이루고 있으며, 서로 다른 특징을 가지고 있다. 폴리머 재질의 경우 근관벽에 손상을 가하 지 않고 안전하게 적용이 가능하며, 유연성이 뛰어나 좁 고 만곡된 근관에서도 적용이 가능하다. 금속의 경우 금 속의 열전도율이 일반적으로 폴리머 에 비해 높기 때문에 PUI 과정 동안 근관 세정액의 온도 상승이 발생할 수 있 
다. 온도가 상승 할 경우 통상적으로 근관 세정액으로 사 용되는 $\mathrm{NaOCl}$ 의 유기조직 용해 능력이 증가하는 것은 이미 이전 연구들을 통해 확인 할 수 있다. ${ }^{28,29}$ 위와 같이 각 재질에 따른 서로 다른 특징이 존재하며, 이에 따른 근 관 세정 효과 역시 차이가 있을 수 있지만, 현재까지는 해 당 주제에 관한 연구가 따로 이루어지지 않은 실정이다.

본 실험에서 한계점으로 지적 될 수 있는 부분은 점수 체계가 0 - 3 까지 단계별로 나뉘어서 실험값의 편차가 커진다는 부분이다. 잔존하는 상아질 잔사의 양을 더욱 정확한 비교를 하기 위해서는 더 세분화된 평가 방법과, 정량적인 측정 방법이 필요할 것으로 사료된다. 또한 본 연구에서는 단일 직선 근관의 하악 소구치만을 실험 대 상으로 하였지만, 실제 임상에서의 근관은 대부분의 경 우 만곡되어 있으며, 다근치이거나, 근단공이 폐쇄되지 않은 경우도 있을 수 있다. 따라서 다양한 임상 상황을 재현할 수 있는 더 많은 실험이 필요할 것으로 사료된다. 그리고 본 실험에서는 Weak 그룹과 Strong 그룹을 나타 내기 위하여 적용 강도를 “1”과 " 10 ”으로 각각 설정하였 다. 그러나 두 그룹간의 통계적 유의성은 나타나지 않았 는데, 강도에 따른 그룹의 분류를 더 세분화하여 실험을 진행하지 못한 부분이 영향을 줄 수 있을 것으로 보인다. 적절한 PUI의 프로토콜 제시를 위해서는 앞으로 더 많은 실험이 필요할 것이라 생각된다.

\section{결론}

본 실험에서 PUI 적용 강도에 따른 상아질 잔사 제거 의 효율성 차이는 통계적으로 유의하지 않았다. 그러나 Strong 그룹에서 PUI를 1 회 적용할 때 보다, 다회 적용 시 치근단 $1 / 3$ 부위의 세정 효과의 유의미한 증가가 관 찰된다.

\section{Acknowledgements}

이 논문은 2017년도 강릉원주대학교 학술연구조성비 지원에 의하여 수행되었음.

\section{ORCID}

Gun Heo https://orcid.org/0000-0003-4542-9989

Jin-Woo Kim https://orcid.org/0000-0002-0004-0710

Kyung-Mo Cho https://orcid.org/0000-0003-3464-9425
Nyamsuren Enkhbileg https://orcid.org/0000-00033489-5730

Eun-Hye Lee https://orcid.org/0000-0003-3175-5791

Se-Hee Park https://orcid.org/0000-0002-4052-4082

\section{References}

1. Haapasalo M, Endal U, Zandi H, Coil JM. Eradication of endodontic infection by instrumentation and irrigation solutions. Endod Topics 2005;10:77102.

2. Schilder H. Cleaning and shaping the root canal. Dent Clin North Am 1974;18:269-96.

3. Peters OA, Peters CI, Schönenberger K, Barbakow F. ProTaper rotary root canal preparation: effects of canal anatomy on final shape analysed by micro CT. Int Endod J 2003;36:86-92.

4. Weiger R, Elayouti A, Löst C. Efficiency of Hand and Rotary Instruments in Shaping Oval Root Canals. J Endod 2002;28:580-3.

5. Peters OA, Schönenberger K, Laib A. Effects of four Ni-Ti preparation techniques on root canal geometry assessed by micro computed tomography. Int Endod J 2001;34:221-30.

6. Siqueira Jr JF, Rôças IN, Santos SR, Lima KC, Magalhães FA, de Uzeda M. Efficacy of instrumentation techniques and irrigation regimens in reducing the bacterial population within root canals. J Endod 2002;28:181-4.

7. Boutsioukis C, Lambrianidis T, Kastrinakis E. Irrigant flow within a prepared root canal using various flow rates: a computational fluid dynamics study. Int Endod J 2009;42:144-55.

8. Zehnder M. Root canal irrigants. J Endod 2006;32: 389-98.

9. Abou-Rass M, Piccinino MV. The effectiveness of four clinical irrigation methods on the removal of root canal debris. Oral Surg Oral Med Oral Pathol 1982;54:323-8.

10. Chow TW. Mechanical effectiveness of root canal irrigation. J Endod 1983;9:475-9.

11. Weller RN, Brady JM, Bernier WE. Efficacy of ultrasonic cleaning. J Endod 1980;6:740-3.

12. Lee SJ, Wu MK, Wesselink PR. The effectiveness of syringe irrigation and ultrasonics to remove de- 
bris from simulated irregularities within prepared root canal walls. Int Endod J 2004;37:672-8.

13. Al-Jadaa A, Paqué F, Attin T, Zehnder M. Necrotic pulp tissue dissolution by passive ultrasonic irrigation in simulated accessory canals: impact of canal location and angulation. Int Endod J 2009;42:59-65.

14. de Gregorio C, Estevez R, Cisneros R, Paranjpe A, Cohenca N. Efficacy of different irrigation and activation systems on the penetration of sodium hypochlorite into simulated lateral canals and up to working length: an in vitro study. J Endod 2010;36:121621.

15. van der Sluis LW, Versluis M, Wu MK, Wesselink PR. Passive ultrasonic irrigation of the root canal: a review of the literature. Int Endod J 2007;40:41526.

16. Krell KV, Johnson RJ. Irrigation patterns of ultrasonic endodontic files. Part II. Diamond-coated files. J Endod 1988;14:535-7.

17. van der Sluis LWM, Wu MK, Wesselink PR. The efficacy of ultrasonic irrigation to remove artificially placed dentine debris from human root canals prepared using instruments of varying taper. Int Endod J 2005;38:764-8.

18. Hülsmann M, Schade M, Schäfers F. A comparative study of root canal preparation with HERO 642 and Quantec SC rotary Ni-Ti instruments. Int Endod J 2001;34:538-46.

19. Ardila CN, Wu MK, Wesselink PR. Percentage of filled canal area in mandibular molars after conventional root-canal instrumentation and after a noninstrumentation technique (NIT). Int Endod J 2003;36:591-8.

20. De-Deus G, Barino B, Zamolyi RQ, Souza E, Fonseca A Jr., Fidel S, Fidel RA. Suboptimal debridement quality produced by the single-file F2 ProTaper technique in oval-shaped canals. J Endod 2010;36:1897-900.

21. Căpută PE, Retsas A, Kuijk L, Chávez de Paz LE, Boutsioukis C. Ultrasonic irrigant activation during root canal treatment: A systematic review. J Endod 2019;45:31-44.e13.

22. Jiang LM, Verhaagen B, Versluis M, Langedijk J, Wesselink P, van der Sluis LW. The influence of the ultrasonic intensity on the cleaning efficacy of passive ultrasonic irrigation. J Endod 2011;37:688-92.

23. Macedo R, Verhaagen B, Rivas DF, Versluis M, Wesselink P, van der Sluis L. Cavitation measurement during sonic and ultrasonic activated irrigation. J Endod 2014;40:580-3.

24. Verhaagen B, Boutsioukis C, Heijnen GL, van der Sluis LWM, Versluis M. Role of the confinement of a root canal on jet impingement during endodontic irrigation. Experiments in Fluids 2012;53:1841-53.

25. Macedo RG, Robinson JP, Verhaagen B, Walmsley AD, Versluis M, Cooper PR, van der Sluis LW. A novel methodology providing insights into removal of biofilm-mimicking hydrogel from lateral morphological features of the root canal during irrigation procedures. Int Endod J 2014;47:1040-51.

26. Boutsioukis C, Kastrinakis E, Lambrianidis T, Verhaagen B, Versluis M, van der Sluis LW. Formation and removal of apical vapor lock during syringe irrigation: a combined experimental and Computational Fluid Dynamics approach. Int Endod J 2014;47:191-201.

27. Robinson JP, Macedo RG, Verhaagen B, Versluis M, Cooper PR, van der Sluis LWM, Walmsley AD. Cleaning lateral morphological features of the root canal: the role of streaming and cavitation. Int Endod J 2018;51 Suppl 1:e55-e64.

28. Cunningham W'T, Balekjian AY. Effect of temperature on collagen-dissolving ability of sodium hypochlorite endodontic irrigant. Oral Surg Oral Med Oral Pathol 1980;49:175-7.

29. Abou-Rass M, Oglesby SW. The effects of temperature, concentration, and tissue type on the solvent ability of sodium hypochlorite. J Endod $1981 ; 7: 376-7$ 


\section{초음파 세정 프로토콜에 따른 근관 내 잔사 제거의 효율성 비교}

허건 ${ }^{1}$ 전공의, 김진우 ${ }^{1}$ 교수, 조경모 ${ }^{1}$ 교수, Enkhbileg Nyamsuren ${ }^{1}$ 대학원생, ${ }^{2}$ 교수, 이은혜 ${ }^{1}$ 대학원생, ${ }^{3}$ 임상교수, 박세희 $^{1 *}$ 교수

${ }^{1}$ 강릉원주대학교 치과대학 치과보존학교실

${ }^{2}$ 몽골 국립의과학대학교 치과대학

${ }^{3}$ 한양대학교 의과대학 치과학교실 치과보존과

목적: 본 연구의 목적은 Passive Ultrasonic Irrigation (PUI) 적용 강도 및 적용 횟수에 따른 상아질 잔사 제거의 효율성 비교에 있다.

연구 재료 및 방법: 48 개의 하악 소구치를 표준화하고 이등분 한 후, 한쪽 상아질벽에는 치근첨에서 $1,3,5 \mathrm{~mm}$ 의 거리에, 반대쪽 상아질벽에는 $2,4 \mathrm{~mm}$ 의 거리에 함요를 형성하였다. 각 함요에 $\mathrm{NaOCl}$ 과 혼합된 상아질 잔사를 채웠다. 치아는 PUI 적용 강도에 따라 'Weak'과 'Strong'의 2개 그룹으로 나누고(n = 24), PUI 적용 횟수에 따라 ‘ 1 회', '2회’, ‘3회’의 3개 그룹으로 $(\mathrm{n}=8)$ 다시 나누었다. 근관 세정 과정 이후 함요에 잔존하는 상아질 잔사의 양을 평가하였다.

결과: Weak 그룹과 Strong 그룹 간의 통계적 유의성은 관찰되지 않았다. Weak 그룹 내에서 PUI 적용 횟수에 따른 통계 적 유의성 역시 관찰되지 않았다. 그러나 Strong 그룹에서 PUI를 2회, 3 회 적용하였을 때, 1 회의 경우보다 유의하게 낮은 상아질 잔사의 양이 관찰되었다.

결론: PUI 적용 강도에 따른 상아질 잔사 제거의 효율성은 통계적으로 유의한 차이가 없었다. 그러나 Strong 그룹에서 $\mathrm{PUI}$ 를 다회 적용시, 1 회 적용할 때 보다 근단 $1 / 3$ 부위의 세정 효과가 증가한다.

(구강회복응용과학지 2020;36(2):104-11)

주요어: 근관 세정; 하악 소구치; 수동적 초음파 세정; 횟수; 강도

*교신저자: 박세희

(25457)강원도 강릉시 죽헌길 7 강릉원주대학교 치과대학 치과보존학교실

Tel: 033-640-2760 | Fax: 033-640-3103 || E-mail: drendo@gwnu.ac.kr

접수일: 2020년 4월 22일 | 수정일: 2020년 5월 7일 || 채택일: 2020년 5월 28일 